\title{
Effect of Black Seed Alkaloids Against some Pathogenic Bacteria
}

\author{
Abdulilah S. Ismaeil \\ Department of Biology \\ College of Science \\ University of Salahaddin \\ Erbil \\ abdulillah1@yahoo.com \\ (Received 13/3/2011; Accepted 6/6/2011)
}

\begin{abstract}
Alkaloids were separated from black seed by using two type of solvents; ethanol and chloroform, we obtained two fractions of alkaloid (A1 and A2). Separated fractions were tested in different concentrations $50,75,100,125$ and $150 \mathrm{mg} / \mathrm{ml}$ against four types of bacteria

(Staphylococcus aureus, Bacillus cereus, E. coli and Pseudomonas spp.). The results showed that both fractions of alkaloid have antibacterial activity against tested bacteria but the effect of A1 was more than A2 and Gram positive bacteria were more sensitive than Gram-negative bacteria, the inhibition zone increased by increasing concentration of alkaloid in all tested bacteria.
\end{abstract}

Keywords: Alkaloid, Antibacterial, Staphylococcus aureus, Bacillus cereus, E. coli, Pseudomonas spp.

\section{تأثيرقاوبدك الحبة السوداء عل مجموعةمن البكتربا الممرضة}

\section{المالخص}

مُ عزل القلويدات من بذور الحبة للسوداء بلستعمل نوعين من المذيبت هما الايثانول و الكلوروفورم

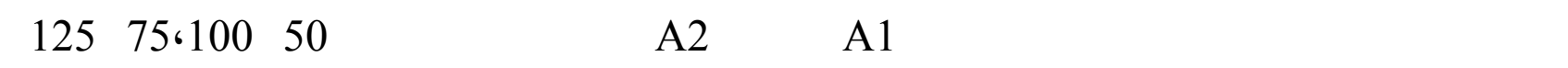

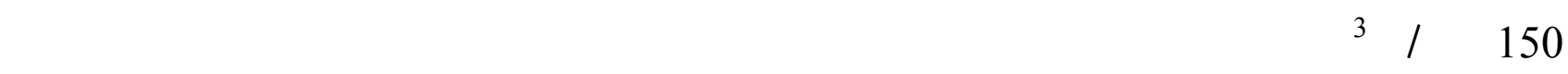
غرلم هي: - Staphylococcus aureus , Bacillus cereus, E. coli and Pseudomonas spp. لطألهرت النتائج أن كلا المستخلصين لهما تأثير مثبط على نمو جمبع أنواع البكتري L الم ستخدمة ف في

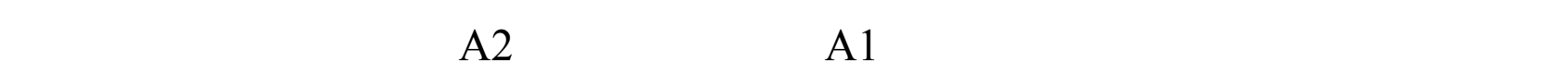

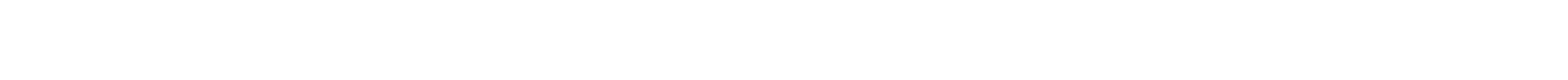
التركيز. 


\section{INTRODUCTION}

Plant extracts and essential oil showed a broad range of pharmacological effects such as anti diabetic (Al-Awadi et al., 1991 ; Farah et al., 2002). The extracts of the plant also showed anti microbial effects (Salomin et al., 1992 ; Chakravaty, 1993). Seeds of Nigella sativa L. (Ranunculaceae) commonly known as black seed or black cumine, are used in folk (herbal) medicine all over the world for the treatment and prevention of a number of diseases and conditions that include asthma, diarrhea and dyslipidaemia (Ali and Blundea, 2003). Seeds of Nigella sativa, have been employed for thousands of years as a spice and food preservative; The oil and seed constituents, in particular thymoquinine, have shown potential medicinal properties in traditional medicine (Salem, 2005). The proteins fractionated from the plant showed immune modulator effect using non-activated or mitogen activated cells (Salim and Fukushima, 2003). The crude and ethanol extract of the seed showed hepatoprotective activity (Worther et al., 1998 ; Daba and Abdel-Rahman, 1998). The addition of black seed to feed of pigeons could act as an immunoprotective agent when chronic administration of antibiotics are considered (Al-Ankari, 2005).

Seed extracts from six species of the genus Nigella (Family Ranunculaceae)-Nigella arvensis, Nigella damascena, Nigella hispanica, Nigella nigellastrum, Nigella orientalis and Nigella sativa obtained by successive extraction with n-hexane, chloroform, and methanol, tested for their antimicrobial activity against 10 strains of pathogenic bacteria and yeast, anti-inflammatory screening revealed that $N$. sativa, $N$. orientalis, $N$. hispanica, $N$. arvensis $\mathrm{n}$-hexane extracts, and $N$. hispanica chloroform extracts had strong inhibitory activity (Landa et al., 2009). Hanafy and Hatem studied the antimicrobial activity of black seed extract on certain pathogenic Gram positive and Gram negative bacteria, but they noticed that black seed has no effect on Salmonella typhimurium (Hanafy and Hatem, 1991). Nigella sativa is a herbaceous plant, whose seeds (black seed) have been used as a spice and condiment in foods in the Middle East (Zaha et al., 2008). The antiyeast activity of the black cumin seed Nigella sativa quinones dithymoquinone, thymohydroquinone and thymoquinone are active antiyeast agents that could be used in the dairy industry as chemical preservatives (Halamova et al., 2010). Nigella sativa oil reduced Hymenolepis nana eggs starting from second day of the treatment until necropsy day during 5 days due to its stimulating immune system.(Ayaz et al., 2007). Thymoquinone inhibited $80-100 \%$ of the fungal growth which support its use in folk medicine for the treatment of fungal skin infections (Aljabre et al., 2005). The steam -distilled essential oil of Iranian black cumin seed was investigated for its composition and analgesic and anti inflamatory properties after oil analysis, (20) compounds were identified among them para- cymene and thymoquinone has an important role in pharmacological effects (Hajhashemi et al., 2004).

In the current work, the inhibitory effect of alkaloid extracts from Nigella sativa L. seeds were studied against the growth of Staphylococcus aureus, Bacillus cereus, E. coli and Pseudomonas spp., to demonstrate its antibacterial effects, bearing in mind that natural products may play a future role by replacing or substituting antibiotics that face the great threat of over all resistance. 


\section{Materials}

\section{MATERIALS AND METHODS}

1- Bacterial strains :-

Staphylococcus aureus, E. coli and Pseudomonas spp. obtained from Hawler teaching hospital laboratory, Bacillus cereus isolated from food sample in the college of ScienceSalahaddin university. All strains identified by biochemical tests ( Barrow and Feltham, 1993).

2- Nutrient agar and Nutrient broth.

3- Pepton water $0.1 \%$.

4- black seed ( From local market).

5- Ethanol, chloroform, silica gel 60.

\section{Methods}

\section{Isolation of alkaloids}

Eighty gram of Nigella sativa seed were ground and defatted with petroleum ether extracted with ethanol $96 \%$ using soxhlet apparatus, the extract then evaporated by rotary evaporator.

The ethanol extract was acidified with $2 \%$ hydrochloric acid, filtered, made basic with concentrated ammonium hydroxide and extracted with chloroform. The chloroform extract were evaporated by rotary evaporator to afford a total alkaloid. Total alkaloid were chromatographed on an open colum packed with silica gel 60. Elution with chloroform followed by increasingly polar solvent chloroform and ethanol. After evaporation of solvents the fractions from chloroform only $\left(\mathrm{A}_{1}\right)$ and the fractions from ethanol only $\left(\mathrm{A}_{2}\right)$ were monitored by thin layer chromatography and ultra violet chromatography (Akbar et al., 1988).

\section{Antibacterial activity}

With a sterile wire loop four to five colonies from each bacteria were touched and transferred to $10 \mathrm{ml}$ nutrient broth, the tubes were incubated for $12-18$ hours at $37^{\circ} \mathrm{C}$, a volume of $0.1 \mathrm{ml}$ of the suspension was transferred to $9.9 \mathrm{ml}$ broth to obtain $1 / 100$ dilution..

The bacterial inoculum was uniformly spread using sterile cotton swab on a sterile Petri dish Muller Hinton agar. $50 \mu \mathrm{L}(50,75,100,125$ and $150 \mathrm{mg} / \mathrm{mL}$ from fractions ) of extracts were added to each of the 5 wells $(7 \mathrm{~mm}$ diameter holes cut in the agar gel, $20 \mathrm{~mm}$ apart from each other) with three replications for each concentration. The systems were incubated for $24 \mathrm{~h}$ at $37^{\circ} \mathrm{C}$ under aerobic conditions. After incubation, confluent bacterial growth was observed. Inhibition zone of the bacterial growth was measured in $\mathrm{mm}$ (Cleidson et al., 2007).

\section{Statistical analysis}

One-way duncan test was used to analyze the obtained data. 


\section{RESULTS AND DISCUSSION}

The two alkaloid fractions (A1 and A2), the ultra violet chromatograph of both fractions shown in Fig. (1) and Fig. (2), this fractions were extracted from ethanol extraction of Nigella sativa seeds, A1 obtained by using chloroform and A2 obtained by using methanol as a solvent (Akbar et al, 1988). The effect of different concentrations of both alkaloid fractions (A1 and A2) were shown in Table (1) and Table (2), as shown, both alkaloid fractions had antibacterial activity against each of Staphylococcus aureus, Bacillus cereus, E. coli and Pseudomonas spp. but alkaloid A1 was more effective than alkaloid A2 toward all tested bacteria [ may be due to differences of both type of alkaloids in their sensitivity because different solvents gives different type of alkaloids (Akbar et al., 1988) ] and we observed increasing the concentration in both fraction increased the inhibition zone against all bacteria but some of them have no significant differences, the Gram-positive bacteria were more sensitive than Gram-negative bacteria [ the reasons may be due to differences in cell envelop of both type of bacteria because the cell envelop of Gram-negative bacteria is more complex than Gram-positive bacteria therefore the Gram-negative bacteria was more resistance than Gram-positive bacteria (Ryan and ray, 2004) ].

Our results are in agreement with Karib and Mawlood which reported that black seed oil has antimicrobial activity against Staphylococcus aureus (Karib and Mawlood, 2001). Also with Alberezhy which reported that the oil of Nigella sativa has antimicrobial activity against Bacillus cereus (Alberezhy, 2002).

Nigella sativa L. has inhibitory effect on methicillin resistant Staphylococcus aureus (MRSA) this finding warrants necessity of further investigation of this product of folk medicine (Hanan et al., 2008). The black cumin or Nigella sativa L. seeds have many acclaimed medicinal properties such as bronchodilatory, hypotensive, antibacterial, antifungal, analgesic, anti-inflammatory and immunopotentiating and are universally accepted as a panacea ( Khan, 1999). It has been reported that Nigella sativa oil have protective effect against murine cytomegalovirus infection (Salem and Hossain, 2000).

Nigella sativa seeds possess clinically useful anti- $H$. pylori activity, comparable to triple therapy clarithromycin, amoxicillin, omeprazole (Salem et al., 2010). Nigella sativa L. seed essential oils obtained by hydrodistillation, dry steam distillation, steam distillation of crude oils obtained by solvent extraction and supercritical fluid extraction were tested for their antibacterial activities, all oil samples were significantly more active against Gram-positive than against Gram-negative bacteria. Thymoquinone exhibited potent growth-inhibiting activity against Gram-positive bacteria, with MICs ranging from 8 to $64 \mathrm{microg} / \mathrm{ml}$ (Kokoska et al., 2008). 
Table 1: Mean \pm standard error of inhibition zone diameter with mm of alkaloid A1 against tested bacteria .

\begin{tabular}{|c|c|c|c|c|c|}
\hline \multirow{2}{*}{$\begin{array}{l}\text { Types of } \\
\text { bacteria }\end{array}$} & \multicolumn{5}{|c|}{ Concentrations of $\mathrm{A} 1 \mathrm{mg} / \mathrm{ml}$} \\
\hline & 50 & 75 & 100 & 125 & 150 \\
\hline $\begin{array}{c}\text { Staphylococcus } \\
\text { aureus }\end{array}$ & $22.33 \pm 0.33^{\mathrm{a}}$ & $25.33 \pm 0.33^{b}$ & $30.0 \pm 0.57^{\mathrm{c}}$ & $32.66 \pm 0.33^{d}$ & $35.33 \pm 0.33^{\mathrm{e}}$ \\
\hline $\begin{array}{l}\text { Bacillus } \\
\text { cereus }\end{array}$ & $23.0 \pm 0.00^{\mathrm{a}}$ & $27.66 \pm 0.33^{b}$ & $30.66 \pm 0.66^{\mathrm{c}}$ & $33.0 \pm 0.57^{\mathrm{d}}$ & $35.0 \pm 0.57^{\mathrm{e}}$ \\
\hline E. coli & $18.66 \pm 0.33^{\mathrm{a}}$ & $22.33 \pm 0.33^{b}$ & $26.0 \pm 0.57^{\mathrm{c}}$ & $28.33 \pm 0.33^{\mathrm{d}}$ & $28.66 \pm 0.33^{\mathrm{d}}$ \\
\hline $\begin{array}{c}\text { Pseudomonas } \\
\text { spp. }\end{array}$ & $17.66 \pm 0.33^{\mathrm{a}}$ & $21.66 \pm 0.33^{b}$ & $24.0 \pm 0.57^{\mathrm{c}}$ & $26.66 \pm 0.33^{d}$ & $27.66 \pm 0.66^{d}$ \\
\hline
\end{tabular}

Same letter in the same raw means non significant at $(\alpha=0.05)$

Table 2: Mean \pm standard error of inhibition zone diameter with $\mathrm{mm}$ of alkaloid A2 against tested bacteria .

\begin{tabular}{|c|c|c|c|c|c|}
\hline \multirow{2}{*}{$\begin{array}{c}\text { Types of } \\
\text { bacteria }\end{array}$} & $\mathbf{5 0}$ & $\mathbf{7 5}$ & $\mathbf{1 0 0}$ & $\mathbf{1 2 5}$ & $\mathbf{1 5 0}$ \\
\cline { 2 - 6 } & $\mathbf{5 0}$ & $\mathbf{5}$ & \\
\hline $\begin{array}{c}\text { Staphylococcus } \\
\text { aureus }\end{array}$ & $19.33 \pm 0.33^{\mathrm{a}}$ & $23.33 \pm 0.33^{\mathrm{b}}$ & $28.3 \pm 0.66^{\mathrm{c}}$ & $30.00 \pm 0.00^{\mathrm{d}}$ & $32.66 \pm 0.57^{\mathrm{e}}$ \\
\hline $\begin{array}{c}\text { Bacillus } \\
\text { cereus }\end{array}$ & $21.0 \pm 0.00^{\mathrm{a}}$ & $24.66 \pm 0.33^{\mathrm{b}}$ & $26.66 \pm 0.66^{\mathrm{c}}$ & $29.33 \pm 0.66^{\mathrm{d}}$ & $32.33 \pm 0.33^{\mathrm{e}}$ \\
\hline E. coli & $16.0 \pm 0.00^{\mathrm{a}}$ & $20.66 \pm 0.881^{\mathrm{b}}$ & $23.66 \pm 0.33^{\mathrm{c}}$ & $24.66 \pm 0.33^{\mathrm{cd}}$ & $25.66 \pm 0.33^{\mathrm{d}}$ \\
\hline $\begin{array}{c}\text { Pseudomonas } \\
\text { spp. }\end{array}$ & $15.00 \pm 0.00^{\mathrm{a}}$ & $21.33 \pm 0.33^{\mathrm{b}}$ & $22.66 \pm 0.66^{\mathrm{b}}$ & $26.33 \pm 0.33^{\mathrm{c}}$ & $28.66 \pm 0.66^{\mathrm{d}}$ \\
\hline
\end{tabular}

Same letter in the same raw means non significant at $(\alpha=0.05)$ 
Abdulilah S. Ismaeil
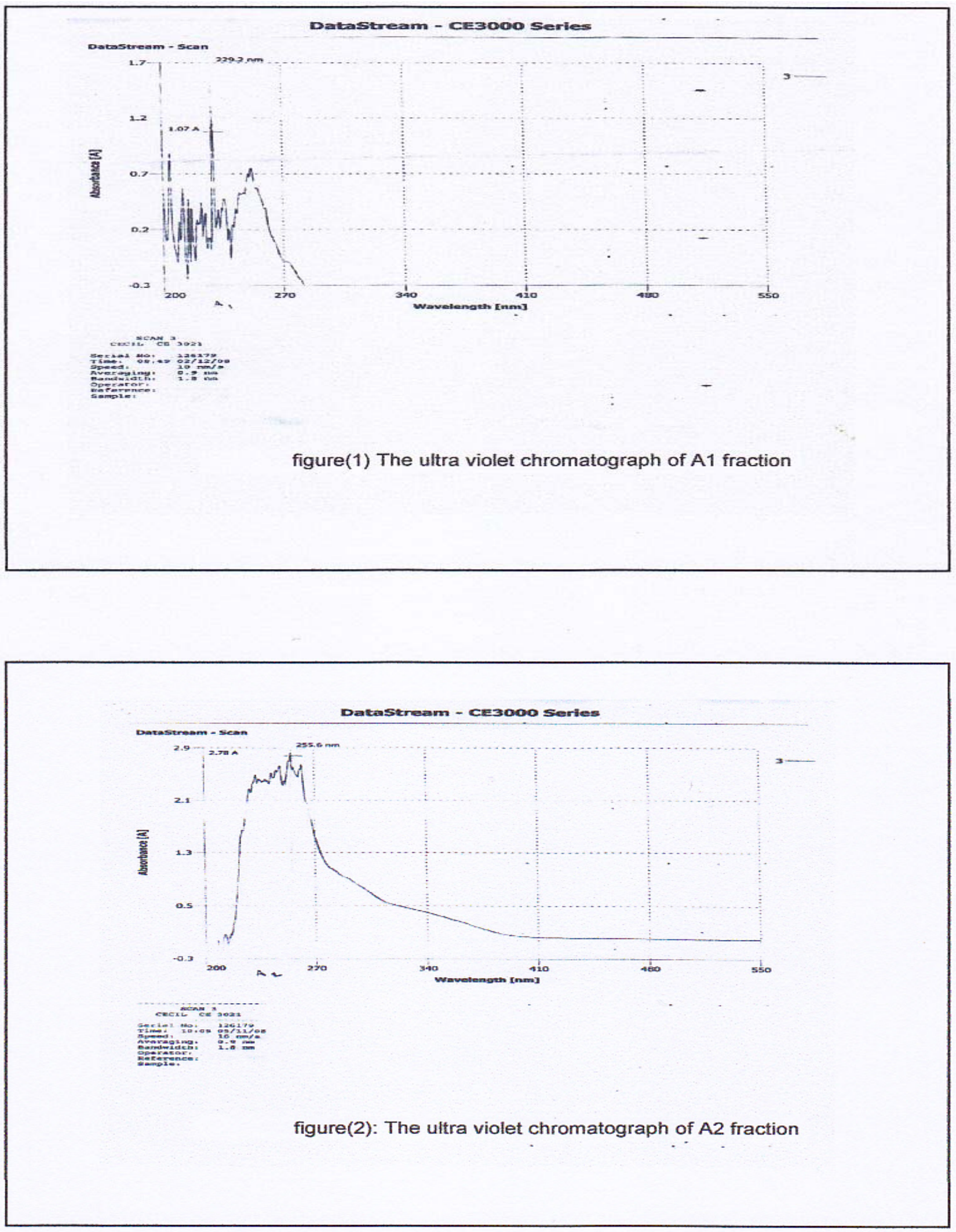


\section{REFERENCES}

Akbar, A.A. ; Sadiq, H. ; Lennart, K. ; Atta, U.R. ; Thomas, W. (1988). Structural studies on a saponin isolated from Nigella sativa . Phytochemistry, 27(12), 79-3977 .

Al-Ankari, A. S. (2005). Immunomodulating effects of black seed and oxytetracycline in pigeons. Immunopharmacol Immunotoxicol., 27(3), 20-515.

Al-Awadi, F.; Fatania, H. ; Shamte, U. (1991). The effect of plant mixture extract on liver gluconeogenesis in strepto zotocin induced diabetic rats. Diabetes Res., 18(4), 8163.

Alberezhy, F. A. Q. (2002). Isolation and identification of Bacillus cereus from some local foods in Erbil city center. M.Sc. thesis, Salahaddin University- College of Science.

Ali, B.H. ; Blundea, G. (2003). Pharmacological and toxicological properties of Nigella sativa L. seeds. Phyto. Ther. Res., 17(4), 299-305.

Aljabre, S. H. ; Randhawa, M. A. ; Akhtar, N. ; Alakloby, O. M. ; Alqurashi, A. M. ; Aldossary, A. (2005). Antidermatophyte activity of ether extract of Nigella sativa and its active principle, thymoquinone. J. Ethnopharmacol., 101(1-3), 9-116.

Ayaz, E. ; Yilmaz, H. ; Ozbek, H. ; Tas, Z. ; Orunc, O. (2007). The effect of Nigella sativa oil against Aspiculuris tetraptera and Hymenolepis nana in naturally infected mice. Saudi Med. J., 28(11), 7-1654.

Barrow, G. I. ; Feltham, R. K. A. (1993). "Cowan and Steel's Manual for the Identification of Medical Bacteria". 3rd edn., Cambridge University Press. pp. 55, 89, 111, 130.

Chakravaty, N. (1993). Inhibition of histamine release from mast cells by nigellone. Ann. Allergy, 70(3), 42-237.

Cleidson, V. ; Simone, M. S. ; Elza, F. S. ; Artur, S. J. (2007). Screening methods to determine antibacterial activity of natural products. Brazilian J. Microb., 38, 369380.

Daba, M.H. ; Abdel-Rahman, M.S. (1998). Hepato protective activity of thymoquinone in isolated rat hepato cytes. Toxicol lett., 16(1), 9 - 23.

Farah, K. M.; Htoji, Y.; Shimizu, Y. ; Takewaki, T. (2002). Insolino tropic properties of Nigella sativa oil on streptozotocin plus nicotin amide. Diabetic Hamter. Res., 73(3), 82-279.

Hajhashemi, V. ; Ghannadi, A. ; Jafar-abadi, H. (2004). Black Cumin seed essential oil, as a potent analgesic and anti inflammatory drug. Phytother. Res., 18(3), 9-195 .

Halamova, K. ; Kokoska, L. ; Flesar, J. ; Sklenickova, O. ; Svobodova, B. ; Marsik, P. (2010). In vitro antifungal effect of black cumin seed quinones against dairy spoilage yeasts at different acidity levels. J. Food Prot., 73(12), 5- 2291.

Hanafy, M.S. ; Hatem. M. E. (1991). Studies on the antimicrobial activity of Nigella sativa seed(black cumin) J. Ethonpharmacol., 34(3-2), 8-275.

Hannan, A. ; Saleem, S.; Chaudhary, S.; Barkaat, M. ; Arshad, M.U. (2008). Anti bacterial activity of Nigella sativa against clinical isolates of methicillin resistant Staphylococcus aureus. J. Ayub Med Coll Abbottabad., 20(3), 4-72.

Karib, D. J. ; Mawlood, S.I. (2001). Antimicrobial effect of Nigella sativa on Staphylococcus aureus. J. Zanko, 3(1), 37-41.

Khan, M. A. (1999). Chemical composition and medicinal properties of Nigella sativa L. Inflammopharmacology., 7(1),15-35. 
Kokoska, L ; Havlik, J. ; Valterova, I. ; Sovova, H.; Sajfrtova, M.; Jankovska, I. (2008). Comparison of chemical composition and antibacterial activity of Nigella sativa seed essential oils obtained by different extraction methods. J. Food Prot., 71(12),80- 2475.

Landa, P. ; Marsik, P.; Havlik, J. ; Kloucek, P.; Vanek, T.; Kokoska, L. (2009). Evaluation of antimicrobial and anti-inflammatory activities of seed extracts from six Nigella species. J. Med Food, 12(2), 15- 408.

Salem, E. M. ; Yar, T.; Bamosa, A. O. ; Al-Quorain, A. ; Yasawy, M. I.; Alsulaiman, R. M. ; Randhawa, M. A.(2010). Comparative study of Nigella Sativa and triple therapy in eradication of Helicobacter Pylori in patients with non-ulcer dyspepsia. Saudi J. Gastroenterol., 16(3), 14-207 .

Ryan, K. J. ; Ray, C. G. (2004). "Sherris Medical Microbiology , An Introduction of Infectious Diseases". 4th edn. Mcgraw-Hill company. $14 \mathrm{p}$.

Salem, M. L.(2005). Immunomodulatory and therapeutic properties of the Nigella sativa L. seed. Int Immunopharmacol., 5(13-14), 70-1749.

Salem, M. L. ; Hossain, M.S. (2000). Protective effect of black seed oil against murin cytomegalovirus infection. Int. J. Immunopharmacol., 22(9), 729-740.

Salim, E.L. ; Fukushima, S. (2003). Chemo preventive potential of volatile oil from Nigella sativa L. seeds against rat colon carcinogenesis. Nutr. Cancer, 45(2), 195-202.

Salomin, J.; Nair, S. C.; Jayawar dhanan, K.K.; Varghesec, O.; Panikar, K.R. ; Amala, L. (1992). Anti tummor principles from Nigella sativa seeds. Cancer lett., 31(1), 4-6.

Worther, D.R.; Ghoshch, O. A.; Crooks, P. A.(1998). The in vitro anti tumor activity of some crud, and purified compounds of Nigella sativa L. Anticancer Res., 18(3A), $3-1527$.

Zaha, A.A. ; Ashok, K.S. ; Nooman, A.K. ; Makbula, A.H. (2008). Comparative antioxidant activity of some Edible plants. Turk J. Biol., 32,193-196. 